\title{
Travel Delays in the \\ Commercial Countryside with \\ Bret Harte and Sarah Orne Jewett
}

N I 869, BRET HARTE PUBlished "Miggles" in the Overland
Monthly. In this story, a washed-out bridge obliges stagecoach passengers and employees to spend a stormy night in the Sierra Mountain home of a former prostitute. An I 895 issue of the Atlantic Monthly included Sarah Orne Jewett's "The Life of Nancy," a story that focuses on the lifelong but intermittent friendship between a Harvard socialite and a young woman from a coastal Maine fishing-farming community. The events of Jewett's story begin when the Harvard man stays beyond the hunting and fishing season as a city boarder in the young woman's family farmhouse because his friend is nursing an ankle injury. Both local color stories bring about interactions between local and traveling characters with the literary device of a weary and unexpectedly halted traveler, a device that suggests disruption, anomaly, and something vaguely old fashioned. Despite the device's outworn feel, it is actually shorthand for a local and translocal history. By using this device, Harte and Jewett reflect on the changes in the cultures and economies of the places where they became adults and began to write. By weaving the device into their fiction in the way that they do, they work to correct some of the inaccurate and offensive stories about those places repeated by the increasingly numerous travelers, tourists and members of the travel industry moving to or through those places. ${ }^{1}$ They narrate a history that allows for sociability and tenuous respect between social groups who were often in conflict in the course of their lifetimes. Their 
use of this device deserves a more supple reading than local color naration has typically received in literary criticism and American Studies.

Early and mid twentieth-century literary historians tended to treat local color literature as a natural response to existing diversity within the United States, a passive reflection of different places, cultural groups, histories, and geographies. ${ }^{2} \mathrm{~A}$ scholar working from this assumption is unlikely to attribute any history these stories tell to an individual author's creativity or perspicacity. Late twentieth-century writers and scholars argue that most nineteenth-century local color writers tell a version of history that is in retrospect unacceptable because the writers' relatively elite backgrounds led them to be nostalgic or, worse, racist and classist. ${ }^{3}$ For example, in his introduction to an edition of Harte's stories, Wallace Stegner apologizes for the inaccuracy of Harte's depiction of the gold rush (viii-x), and in Tripmaster Monkey ( 1989 ) Maxine Hong Kingston rejects Harte as a precursor because of Harte's racist portrayal of Ah Sin (9-10). In comparison to Harte, Sarah Orne Jewett receives critical acclaim, but usually not for the way she depicts historical change. Scholars fault her for hiding the historical presence of tourism and industrialism in Maine. ${ }^{4}$ Or they apply arguably limiting theories of history to Jewett's work. For example, Richard Brodhead and Sandra Zagarell argue that Jewett scholars should focus on her affiliation with the Northeastern cultural elite and its symbolic and material control over poorer regions and countries, because in Jewett's day this power was overwhelmingly influential in fiction and national affairs. A few scholars dispute this directive. While agreeing with Zagarell and Brodhead that Jewett privileges elite values, June Howard shows how Jewett's "A Late Supper" weaves together the nineteenthcentury ideal of hospitality with modern knowledge of the stock market. This combination of temporalities is not Jewett's naïve reading of her own historical moment, argues Howard, but a sense of history as a process not so easily segmented into periods. Jacqueline Shea Murphy argues that the focus on the interests of the Northeastern elite in Jewett's fiction wrongly assumes that this power was uncontested in Jewett's time and continues to be so today, and she shows how Jewett's work did not prevent Abenaki Indians from telling other stories about Maine even during Jewett's lifetime. Murphy, like Patricia Nelson Limerick and Elsa Barkley Brown, works from a de-centered theory of history, in which, in Brown's words, "History . . . is everybody talking at 
once" and "The events and people we write about did not occur in isolation but in dialogue with a myriad of other people and events" (274). In this article I argue that there are signs of the contest and conversations between different historical groups in the stories "Miggles" and "The Life of Nancy." I also argue that readers can read these stories and other writings by Harte to de-center the histories of California and Maine, to wrest away a degree of control from the centralizing and organizing forces of economic development. I will show that Harte and Jewett wrote from a local perspective, that of local cultural arbiters, not a perspective granted much overt attention in literary criticism or American Studies. They represent history in an active manner, in a way that is neither nostalgic for a putatively conflict-free past nor always evasive of the writers' trans-local, commercial present.

\section{TRAVEL, REGIONAL ECONOMIES, AND EMERGENCY HOSPITALITY STORIES}

The stories become readable as optimistic but not inaccurate stories about historical change when one considers them next to the specific changes in regional economies that occurred from the 1850 s to the I 890 s. In the course of these decades, the cultures and economies of New England and California were dramatically reshaped by changes in tourism, travel, and economic development that modified the way that travelers interacted with local residents. ${ }^{5}$ Migrants, business travelers, and tourists continued to stop unannounced at private homes, as they had done throughout the European settling of the American continent. But for the first time in the continent's history, they did so in the context of many other options. As historians of nineteenth-century tourism have conclusively demonstrated, travel became speedier and more commercial during the century. ${ }^{6}$ For eating, sleeping, or resting, travelers relied decreasingly on local people and increasingly on translocal corporations, travel agents, government agencies, and travel guides. The wealthiest travelers were able to choose between different levels of cost and comfort. Elite hotels, with private rooms, private washrooms, and increased personal services, were built in new cities and tourist destinations, modeled after the Tremont Hotel in Boston (established I 829) and the Astor House in New York (established 1834) (Yoder 80). Or travelers could stay in lower-priced hotels, boarding houses, or tent 
cities. On trains and steamboats travelers had always been separated by race, class, and family status, and by the end of the r88os, non-black and non-Chinese travelers with money chose between eating and sleeping in the luxury Palace Pullman cars or cooking their own food in the Tourist Pullman cars, which were equipped with stoves and ice chests (Fifer 327-33). Thus, for the first time in U.S. history, travel hindered rather than fostered interactions between travelers of different classes and between travelers and people outside the travel-service industry.

Modernization happened unevenly across the country, but as soon as luxury accommodations or transportation choices were available in a specific location, travelers who could afford to use them did so. Thus on a local level modernization was swift and seemingly irrevocable. Local business people were forced to adjust. People who previously made money by doing travelers' laundry, cooking their meals, or transporting them by stage had to cooperate with refined and efficient competitors who were quickly and powerfully changing the rules of the trade. For example, according to the traveler W. G. Marshall, a local man in Yosemite was forced by the large hotels to remove his sign advertising laundry services from one of the area's viewpoints (343-44). When the man discussed the event with Marshall, the man speculated that the park officials were interested not only in preserving the natural view but also in keeping competing businesses at bay.?

While these changes in regional economies were occurring, people changed the stories they told about hospitality. They began to focus on the newly antiquated feel of spontaneous, bartered hospitality. Suddenly instances in which travelers received assistance, food, or shelter from people outside the travel industry felt unusually human and warm. Throughout the century, narratives of emergency hospitality appeared widely: in pioneer diaries, in travel literature of the elite and middle classes, and in genteel American or European fiction. In the 1830 , entering the home or "crude" inn of a stranger was something that travelers and tourists did when alternative accommodations were not available, as did Caroline Kirkland and Margaret Fuller in their trips to the Great Lakes region in 1837 and 1843 respectively. Although writers mention the incident, they do not always remark upon it at length. ${ }^{8}$ But by the 1850 , the act was both a practical activity and a meaningful piece of supposedly authentic experience worth fantasizing about be- 
forehand and narrating afterward, as it was to Albert Richardson in his travels as a reporter through the Great Plains-in one incident, after taking shelter in an Indian cabin on a stormy night, he returned with his wife so that she could experience the Indians' hospitality first hand. ${ }^{9}$ By the end of the 1860 s, such visits in most parts of the United States were ready candidates for intense and unique experience.

Emergency hospitality stories reflect on the possibility of egalitarian and unscripted moments within a travel culture that is otherwise hierarchical and formulaic. ${ }^{10}$ They suggest that human interactions coexist with market transactions, sometimes even in the present day. The ideological potential of such stories is mixed and can be co-opted for different purposes by different authors and audiences. Some stories emphasize that kindness can occur in the present time in spite of economic inequality, and others shore up readers' sense of themselves as modern and distinct from the quaint accommodations and people of the past. In the specific cultural location in which Harte's and Jewett's stories were first published, arts and letters magazines too expensive for most middle- and lower-class people to buy, the message of the writers' superior modernity became the more prevalent. ${ }^{11}$ Stories of unplanned visits with lower-class locals appeared, albeit infrequently, in similar magazines between the 1860 s and the 1890 s. In 1870 , the Atlantic Monthly published a story, M. Edward Brown's "A Winter Adventure on the Prairie," in which four day trippers drive a horse to death, run from Indians, and spend the night in a cabin of a French-Indian family. The traveling party consists of residents of a prairie town and their female friend from the East, who serves as the story's narrator. Bridging two publishing fields, this story resembles those narrated in overland diaries and fiction as well as those published in the high literary monthlies; the death of a horse would have been a major financial blow for prairie residents, and the night sleeping on a mixed-race family's floor would have registered as a foray into barbarism for many middle-class people, including those who lived on the prairies. The story is witty, with the narrator expressing resignation to the moment rather than fear of humiliation or pride in her own ability to endure. ${ }^{12}$ In $187 \mathrm{I}$, the pages of Harper's Monthly included a quaint old man who invited tourists into his home on the outskirts of Key West (Holder), and in 1875 the magazine printed a story about a group of sport fishermen who spent a pleasant night in a rude backcountry hotel on the Maine-Canadian 
border (Ward). In these later stories the device of emergency hospitality serves as a moment of novelty, a way to market stories as more authentic to a real locale outside of the standardizing forces of mass tourism. Writes the traveler who visited the old man in Key West, "We are fond of these choice bits of living pictures" (Holder 314 ). Premised on readers' sense that sleeping on the floor means crisis, discomfort, and danger, the latter stories build readers' sense of themselves as modern and cosmopolitan because they are able to tolerate unpleasantness with the knowledge that it will not last forever. Yet emergency hospitality stories of any stripe did not overtake the pages of the arts and letters monthlies; lest one overstate their appeal for the cultural elite, one should remember that Henry James's character Lydia Touchett in The Portrait of a Lady (I88I) dislikes all American hotels, much less the backcountry ones.

And to read all emergency hospitality stories solely from the travelers' perspectives is to reassert the supremacy of the late nineteenthcentury cultural elite. Harte and Jewett emphasize in their emergency hospitality stories that such events were instances in which travelers bump up against competing modern realities, against people who are as modern as themselves, albeit in different ways. ${ }^{13}$ They at once encourage readers to think about the possibility of friendly acts between strangers and remind readers of the social antipathy that made such friendliness difficult in real life. As I will explain in the following sections, in opposing ways, the stories can help scholars understand the relationship between local color writers and historical change like the oncoming of tourism and between local color writers and the feminine. The stories illustrate the in-between role of local color fiction writers in the telling of a national history, and they are especially notable because they do not obscure the feminine work of feeding and caring for others.

\section{HARTE AND "FRONTIER" HOSPITALity}

In some of the newspaper sketches that Harte wrote before he left California, he strives to occupy a middle position between California residents and newcomers from the East or elsewhere. In the process he de-centers tourism by telling readers that some of the regional people are literary types, too, and that there are places worth visiting other than Yosemite or the Sequoia Trees, like the Santa Clara valley, or, in 
"Miggles," the cabin of a single woman who manages to take care of a disabled man. The newspaper sketches are set in Harte's own present, and "Miggles" retells a story of the past in a way that reveals respectable men's hypocrisy about sex outside marriage.

Harte's story of stagecoach passengers who spend a night in a "frontier" home relies upon a history and mythology of road travel and backcountry accommodations. Before the railroad, road travel by foot, horseback, or horse-drawn vehicle was legendarily difficult. It exposed travelers to weather, terrain, and the volatile wills of animals and people. Travelers had to stop often and randomly. They relied on networks of settlers, traders, missionaries, and Indians (Limerick 38-4I; Unruh 268). Private families and innkeepers alike took on extra roles in times of need. They regularly cared for guests who were ill, and they sometimes served as physicians or undertakers in the absence of alternatives (Yoder 33-34). Even elite travelers like Margaret Fuller accepted help from humble farmers and Indians.

These aspects of road travel and backcountry accommodations fed the ideal known then and now as "frontier hospitality," in which different social groups in sparsely settled areas freely provided guidance, supplies, and shelter to travelers in boundless and spontaneous ways. ${ }^{14}$ The actual experience of individual travelers and residents behind the ideal has been much debated. Scholars who emphasize social conflict as well as consensus have shown that class, ethnic, and sexual friction abounded in real frontier hospitality. Paton Yoder has documented that even inns in developing areas were run by managers working under absentee owners, a fact that should modify fantasies of salt-of-the-earth folk who care for strangers out of the goodness of their hearts $(6,13,9)$. Travelers and hosts from different ethnic groups or political parties were sometimes friendly to each other and sometimes hostile, and many genteel travelers had to work hard not to be openly disgusted by the hygienic standards of roadside taverns.

The seventeen-year-old Bret Harte arrived in Oakland, California in I 854 , at the tail end of a "boom." The gold rush had recently brought large quantities of Eastern money, luxury hotels, construction, and people to the San Francisco bay and the Sierra Nevadas. Born in Albany and raised mostly in New York City, Harte was part of that influx, and by most accounts, an outsider in long-term residents' eyes. ${ }^{15}$ Granted, he served briefly as a stagecoach expressmen, and in the 1850 se 
recuperated in the cabin of miner Jim Gillis for four days, thus experiencing frontier hospitality first hand (Nissen 43-44). He also lived on a ranch and in Uniontown, a town of five hundred people-not as blacksmith or farmer, producing things those communities would have valued, but as tutor and printer's assistant. In the words of Harte biographer Alex Nissen, "Frank [Bret] Harte would emphatically not do in the eyes of the 'rougher element,' as contemporary witnesses attest. . . . As a young man in Oakland, Uniontown, and San Francisco, Frank Harte was never one of the boys" (54). Instead Harte followed his personal desires and worked to become an artist, a writer. Although Richard Brodhead emphasizes the elite dimension of some local color writers' backgrounds and argues that their writing furthers the interests of the elite, Harte was born in a middling state. He came from a family that valued book learning but lacked the money and status to afford him a comfortable life as a writer. So he searched for work. He was discovered and befriended by San Francisco cultural leaders Thomas Starr King and Jessie Frémont, who introduced him to local editors and helped him secure work as a clerk in various government offices. He wrote and edited for local and national papers, and after he married in 1862 , his wife augmented the family income by singing in a church choir (Stewart 140 ). The Harte family lived in increasingly fashionable houses, and by 1865 , it was possible for them to take vacations in the Santa Clara countryside (Stewart I73).

Unlike Jewett, Harte initially aspired to be a writer of universal rather than local subject matter, and he seems to have been drawn into writing about California through market pressure. In the decade when Harte began writing, San Francisco's literati and businessmen were taking an interest in the gold rush and Spanish California as the state's "past," a past that they could market as part of California's unique identity and yet assure its passing by attracting the railroad and outside investors. A Sacramento newspaper criticized Harte in 1865 for editing a volume of California verse that included no poems with local subject material (Nissen $8 \mathrm{I}$ ). Yet the sketches he published in this period discuss a range of local topics, both urban and rural: a San Francisco bank explosion, memories of the city's defunct German beer garden, a flood in a country village, the social types of a Western stage, and the intrigue of a night-time stageride. ${ }^{16}$ These sketches deal with small-scale 
interactions between the people of California "past" and California "present." They also reveal Harte's in-between subject location.

In Harte's newspaper work, he placed himself as an observer of both the emerging elite and the established agrarians. "In the Country," ( 1865 ) a sketch published in The Californian, a San Francisco-based literary journal, marks an upper and a lower class and leaves unmarked a bohemian middle ground, from which the authorial persona speaks. Describing a country place along the route of fashionable travel, the sketch expresses regret over the destructive influx of economic development. But it also codes local rural people as tragically barbaric:

There was something peculiarly Californian in the occasional odd juxtaposition of civilization and barbarism.... Yet in the midst of this wilderness, a turn in the rough mountain trail brings you suddenly upon a vision of smoothly-shaven faces, pork-pie hats, bright dresses, ribbons and light-colored gloves, in a smart rockaway, drawn by well-groomed horses with shining harness. Perhaps a few yards further on you meet the indigenous oxteam, toiling along with its load of rails, preceded by the teamster, unshaven and unshorn, looking as if he might in time so closely assimilate to his oxen as to change places with them. Such is the influence of civilization, however, that it is the ox team which seems the intruder. The teamster recognizes the fact as he turns out of the way to let you pass. ( $16-17)$

Harte's persona is not equidistant from the ox driver and the pork-pie hats. The interest in the details of the excursionists' dress and the attitude toward the ox driver, as well as the assurance that the ox driver is a member of a "vanishing race," place Harte's unmarked middle ground closer to the ground of the wealthy city people. In spite of erratic finances throughout his life, he exemplifies the disposition that Bourdieu associates with the artist as a dominated member of a dominant class (Bourdieu 33-34, 37-40). Although he narrates another scene in which a well-dressed horseman imperiously orders him off a plot of land, he ridicules local residents who fail to answer his questions for directions along the minor roads: 
[The] effect of a question upon the rural mind was similar to a blow. After the first stunning effect was over, recovery was followed by the attitude of resistance. When an answer could be extracted from these people, it was usually given in a vague, unsatisfactory manner ... . There were allusions to such land marks as Jones' Mill, Brown's Store and Robinson's Fieldlocal authorities of course utterly unknown to the stranger. ( I 7-18)

Here he is teased by the locals no differently than an excursionist might be, and he sounds humiliated. The speaker's earlier attempt to dominate the locals might stem from the fear of such humiliation. Thus scholars should read Harte as between rather than affiliated with either the uncultured locals or the excursionists, but in a way that forces him into moral complicity with the economic changes that were benefiting the comfortable middle class and elite. The very journal in which the sketch was published had higher cultural aspirations than any other previous San Francisco venture, and "ironically, its very existence was made possible by the increased wealth, luxury, and spirit of materialism that the paper would disparage in its columns" (Nissen 77).

Harte tried to argue that he was a better source of information about California than the New England and European tourists whose travel narratives, lithographic plates, and photographs were being published worldwide. In a letter Harte wrote as the California correspondent for the Massachusetts Springfield Republican, he locates himself in his own retreat of the Santa Clara Valley, a valley closer to San Francisco, and thus less expensive to visit, than the world-famous tourist destinations of Shasta, Yosemite, or the Sequoia Trees, which Harte calls "the heroics of California scenery" (I3I). As he strolls through the local lowlevel bureaucrats' summer retreat, he explains why wealthy tourists find Californians impassive and ignorant. It is because the tourists act so silly and hysterical about the scenery: "It is not pleasant to have people around you falling into spasms of admiration and enthusiasm after an hour's acquaintance with things you think you have thoroughly comprehended and which you admire-if at all-with a judicious calmness" (133). As someone who can view Sequoia trees with such composure, he understands that there is good reason for "the halfsuperciliousness and ill-disguised scorn which characterize most guides" 
(133). Sympathizing with one's guides rather than with one's fellow tourists was common among self-identified cosmopolitan travelers. Guides were usually young locals who hired themselves out to help tourists up mountains or through caves. Many wealthy tourists resented guides' impudence, but like Harte before him, Rudyard Kipling, literally on the proverbial Cook's tour (Fifer 205), preferred them to Daisy Miller-like tourists who were increasingly populating the American tourist routes (Kipling 76-1 I2). By sympathizing with guides, Harte is saying that he can lead people through California in an authentic and learned way. More so than the Harper's Monthly writer who claims to be fond of "these choice bits of living pictures," Harte sought to individualize himself with a unique travel experience that separates him from less experienced travelers. James Buzard calls such efforts at traveler individuality a sign of a writer's degree of acculturation to his increasing cultural status. ${ }^{17}$ This was surely the case with Harte, but this particular move is also a bargain with necessity; Harte had to write about a California that Massachusetts readers will recognize even though the California he knows is different, so he praises the California he knows to make himself feel better.

In the story "Miggles," written in California, soon after Harte was invited to become editor of the newly created Overland Monthly, Harte's in-between persona is evident in the form of a well-spoken narrator who views both the stagecoach driver and a garrulous judge from some distance. Like the sketches, it details small-scale negotiations between California "past" and California "present." The story creates a temporary community comprised of the narrator/passenger, a stagecoach driver (the famous Harte character Yuba Bill), an expressman, a judge, a genteel couple from Virginia City, a traveler from the Washoe region of Nevada, a French lady, an Irishman who rides on the roof, the former prostitute Miggles, her paralyzed lover Jim, her tamed bear, and her pet magpie. ${ }^{18}$ It would have been highly unlikely for such a group to interact without serious tension in an actual western public establishment, before or after the railroad. Actual frontier hospitality was human in its prejudice and pettiness as well as its sympathy and humor. So Harte's decision to make this community a pleasant one is an act of defiance. The story suggests that people from different social groups can coexist peacefully even if they do not usually get along.

The story narrates a shift in reader/traveler expectation from hostil- 
ity to cooperation. The first lines detail the atomizing dreariness of American travel complained about by many travel writers of the day. ${ }^{19}$ Although the passengers and driver are physically crowded in the stagecoach, they are metaphysically isolated. They sit in silence during a jolting eight miles, and the ladies fade into an anonymity, a "wild confusion of ribbons, veils, furs, and shawls" $(37)$. The rest of the narrative works to undo this anonymity.

The next lines encourage readers to view the turn of events as a challenge to the characters. Readers think suspense and the unknown; the passengers catch only snatches of the shouted exchange between the driver and a horseman who relays the news "bridge gone," "twenty feet of water," "can't pass," and "Try Miggles," and they wonder aloud to each other about the identity of the person with such a strange name $(37-38)$. Once they arrive at a barred and boarded gate, the decision of what to do next becomes a battle of class styles between the driver and the expressman on the one side and the judge on the other. The driver Yuba Bill's strategy of violently penetrating the gate follows the code of rough masculinity associated throughout the nineteenth century with the lower classes (Bederman I7-I9). At first, his strategy appears the more productive. Bill calls into the gate forcefully and orders the passengers to do the same. They are answered by what sounds like a belligerent male voice, and Bill assumes that a man inside is challenging him. Meanwhile, the judge calls toward the house to kindly "consider the inhospitality of refusing shelter from the inclemency of the weather to helpless females," a line whose gentility is rendered ridiculous when it too is answered by the belligerent male voice $(40)$. It is only when Bill walks into the building, shines his lantern in the eyes of a wrinkled man, and tips him over that the party discovers that the man is paralyzed: "To our great dismay, as Bill removed his hand, the venerable stranger apparently collapsed-sinking into half his size and an undistinguishable heap of clothing" (4I). They soon realize that the belligerent male voice was an echo of their own from the beak of the magpie. The significance of these realizations is that when they dismantle the only visible man of the household, Bill's anticipation of rough challenge becomes irrelevant. Obviously, no one in the cabin wishes them harm.

Rather than choosing the aggressive masculine script, Harte chooses to make the characters work together in a semblance of harmony. He is less subverting all literary convention for once and all time than choos- 
ing a literary convention that suits his purpose. The judge's middleclass self-control and penchant for quoting poetry help to an extent, as he directs the men in sitting the figure back up in his chair before the fire. But it is Miggles who brings the group into a difficult state of sociability, assistance, and discretion. Once she appears, her presence encourages the passengers to change their habitual ways of interacting with people. First, they are shocked that the odd name "Miggles" refers to a woman. Coming in from the rain, Miggles sprays them with raindrops, drops a hairpin while fixing her hair, and asks them to help her pick it up. The ladies shrink from her comfort with the situation; women who worked in, managed, or owned public establishments were in danger of being considered "loose" (Johnson "Bed and Board"). But at her request, the men of the party (from the judge to the expressman) help Miggles grind the coffee, build the fire, and slice the bacon. All present from the judge and the French lady to Yuba Bill and Miggles sit down at the table together to eat. The point of this scene is that human interactions can continue in a relatively peaceful manner despite serious social antagonism.

This social antagonism is not swept away in the writer's attempt to portray the social groups in question as less harmful to each other than they actually were in history. The Irish passenger has to ride on the roof in transit even though he rooms with the rest of them in this extraordinary circumstance. The genteel ladies of the party never quite accept Miggles, and the male writer Harte never renders them much less anonymous than they are in the opening scene. They are sent to sleep in a side room before Miggles explains the reason for her cohabitation with Jim-she left the Polka saloon for her lover and client who was suddenly struck by paralysis-a piece of her life story which serves as the story's climax. Harte's most recent biographer Alex Nissen has found evidence that Harte was willing to speak out on the behalf of Indians, Chinese, and Jews in his editorials for various newspapers, and he has argued convincingly that Harte's "Plain Language from Truthful James" was intended to and actually did prompt contemporary readers to question their habitual distrust of the Chinese $\left(27-30,55-56,75^{-}\right.$ 76, I09-1 I). But the narrator/passenger most similar to Harte writes as if the lower status characters are lower on an evolutionary track: Jim is an "invertebrate," Yuba Bill "growl[s]" and his devotion to Miggles makes him a Caliban to her Miranda (4I, 43, 45). 
Furthermore, the burden of mollifying the fragile community is displaced onto a woman, and even more predictably, a "loose" woman. In nearly all North American cultures, the work of feeding and caring for strangers went to women whenever women were around. In Susan Lee Johnson's analysis of the domestic life of the Gold Rush diggings, male miners had to cook and clean for themselves. But many men, particularly white North Americans or Englishmen, likened themselves at these tasks to white women at home or gendered other races female when they considered such work easier for the supposedly neat Chinese or culinary French. In the more organized context of the Great Plains in the 1850 , Albert Richardson accepted food and sleeping quarters from men and women. But when Mexican, Indian, or white woman were around, they did the cooking, and often they did not eat with the rest of the party. Granted, being the one household around with the resources for housing strangers gave members of that household statusthey got the news first, and they maintained temporary control over where the travelers went and what they knew. Some women probably enjoyed this opportunity, even though it came with strings attached.

To Harte's credit, though, the story encourages readers to see that getting people to be friendly is feminine, thankless work. It is clearly Miggles' discretion and her ability to win over the men of the party that makes it possible for the party to coexist; it is her role to charm the men, appease the ladies, and protect her powerless lover. The narrator highlights the fact that Miggles bears a burden no one else shares:

The meal was a culinary success. But more, it was a social triumph-chiefly, I think, owing to the rare tact of Miggles in guiding conversation, asking all the questions herself, yet bearing throughout a frankness that rejected the idea of any concealment on her own part, so that we talked of ourselves, our prospects, of the journey, of the weather, of each other-of everything but our host and hostess. (46)

Relative peaceful coexistence would not be possible without Miggles' ability to appear frank yet be discreet.

In this way the story does not simply shore up traveler-readers' sense of self or comfortable fantasies of the Wild West. It does not provide a depiction of a woman boarding house proprietor from a woman boarding house proprietor's point of view. The story does, though, raise issues 
of gender, sexuality, and class that other literary fiction of its decade (and the next two decades) does not. Miggles makes it clear that she thinks some of the polite men in the room might have used her services when she was a prostitute. Suddenly she asks, "Is there any of you that knows me?" and when the answer is no she exclaims, "Think again! I lived in Marysville in '53. Everybody knew me there, and everybody had the right to know me" $\left.{ }_{50}\right)$. In the fictional mise en scène, the ladies are not present. But actual ladies read the story. So the story is a safe but potent way for Harte to point to respectable society's hypocrisy about prostitution and cohabitation.

The story "Miggles" hides the commercial nature of the interaction between Miggles and the stagecoach passengers: it was likely that travelers would have paid someone who took them into her home, or at least offered to pay her (Yoder), but in the story there is no discussion of payment. Nor is there any hint that in the 1850 and ' 60 s, nearly every traveler to California was also a tourist, interested in the pleasure of the experience and following to some extent a beaten track.

\section{JEWETT AND THE}

\section{LIFELONG SUMMER BOARDER}

Unlike "Miggles," "The Life of Nancy" comments directly on what commercialized travel has done to the place the author knew well and suggests that human interactions can coexist with commercial transactions into the present day. The story makes a number of subtle moves that counter the typical gender and space politics of emergency hospitality stories and other urban-rural stories of the age. While most emergency hospitality stories depict friendships that are temporary, Jewett imagines what might happen if a friendship begun with emergency hospitality lasted a lifetime. While most emergency hospitality stories depict a mildly battered and temporarily immobilized traveler, she contrasts the Harvard socialite's sprained ankle to the major immobilization of rheumatism which confines the village woman to her family's farmhouse. The story's premise is social-sexual betrayal: the power imbalance and cultural differences between the Harvard socialite (Tom Aldis) and the village woman (Nancy Gale) never leave readers' attention. For instance, the story makes clear that the rheumatism of Nancy's adulthood grows severe because she lacks access to the first-rate med- 
ical help a city woman might secure. Yet rather than turn Nancy into a case study of provincial hardship, a case study that might merely assure readers of their own mobility, Jewett encourages readers to view Nancy as a spiritually strong counterpoint to the city; the title phrase "the life of" makes the story something of a hagiography.

Jewett writes about changes to travel, tourism, and hospitality in a different context from Harte's, the New England village. By the time of Jewett's birth, New Englanders were beginning to recognize that "progress" was moving elsewhere, in part to Harte's country in the West. The traditional industries were not growing, and residents and government officials saw leisure tourism as an appealing economic option. Unlike California, where many of the prospective travelers to whom Harte was writing came with the intention of settling down or investing in a new economy, people came to New England to relax or invest in private or public vacation property. By the $\mathbf{I} 860 \mathrm{os}$, as Dona Brown has shown (I50), the summer vacation had become available not only to artists or the wealthy but also to schoolteachers, ministers, and shopkeepers. This new class of tourists was more likely than wealthy tourists to use inexpensive accommodations, and so the long-standing practice of taking in boarders turned into a formal business. Farming families began reading government publications and advertising in the newspapers to find ways to attract city families to their homes. Although city boarders were often demanding, ignorant, or condescending, they paid cash, which enabled farming families to enter the cash economy more effectively than they could with farming alone. Moreover, it was usually the women's task to care for these city dwellers, and some women maintained individual control over this extra income. Jewett dated the first summer boarders in her hometown of South Berwick, Maine, to the mid i 86os (Weber and Weber viii-ix). Thus in New England when the story was written, people did not only stop at private homes in times of emergency or need, they were expected and planned for, and they paid an arranged fee. The relationship between host and boarder was in this sense overtly commercial.

"The Life of Nancy" depicts these changes in New England tourism in precise detail. The Bostonian character Tom Aldis visits East Rodney, Maine twice in the story. In the first visit, he is a student, accompanied by his student friend Carew, who plans to spend the summer hunting and fishing near his father's property. Tom and Carew stay as 
paying guests in the Gale family farmhouse. This visit might take place around $\mathrm{x} 868$. The second visit is twenty years later, when Tom is a married businessman planning to sell his father's property in East Rodney; this time, Tom stays in a grand hotel owned by a man new to the village. Even though both grand hotels and homes that took in boarders already existed in Maine in the I86os, this shift symbolizes the tourist industry's growth and sophistication.

During this shift, Jewett herself responded to tourism in contradictory ways. She once claimed that her motivation for writing stemmed from a desire to defend Maine residents against insensitive and ignorant summer boarders. She wrote of this desire with a mixture of condescension and respect for Maine people:

the way they [the city boarders] misconstrued the country people and made game of their peculiarities fired me with indignation. I determined to teach the world that country people were not the awkward, ignorant set those people seemed to think. I wanted the world to know their grand simple lives; and, so far as I had a mission, when I first began to write, I think that was it. (qtd. in Weber and Weber viii-ix)

Throughout her life, she defended the pleasures of living in Maine to Boston friends who urged her to stay in Boston year round. Even Annie Fields found South Berwick boring (Blanchard 90), and by the 1890 s Fields was Jewett's primary source of companionship and love. In 1893 , about the time she wrote "The Life of Nancy," ${ }^{20}$ Jewett wrote privately that tourism had become financially and spiritually valuable for both New England and Eastern cities:

It has certainly been a great means of broadening both townsfolk and country folk. I think nothing has done so much for New England in the last decade; it accounts for most of the enlargement and great gain that New England has certainly made, as if there had been a fine scattering or sowing broadcast of both thought and money! (Letter to F. M. Hopkins)

Jewett found appeal in both Berwick and Boston-she liked Berwick's history and supposed coherence and Boston's intellectual stimulation, adventure, and heterogeneity. Louis Renza (47-55) and Sandra Zagarell ("Troubling Regionalism") have interpreted this contradiction in 
Jewett's thinking as a change over time, in which Jewett eventually became sanguine about the problems that had initially inspired her to write. But the second statement and "The Life of Nancy" suggest that even in her maturity Jewett continued to hope that tourism could benefit many classes of New Englanders.

During Tom's first visit, his friend Carew injures his ankle, an event that provides Tom and Carew with the excuse to stay beyond the hunting season. While Carew nurses the injury, Tom socializes with the local youth, including the popular Addie Porter and the respected Nancy Gale. Unlike Jewett's urban friends, Tom is not bored; Nancy's dancing is superlative, he thinks, "one of the most ideal things he had ever known in his life; it would be hard to find elsewhere such grace as hers" (15). Tom and Nancy Gale become so friendly that Tom sends her Christmas presents and letters, and when Nancy visits Boston that winter, Tom accompanies her sightseeing. When Tom returns to East Rodney twenty years later, he visits Nancy, long since bedridden by her rheumatism. His appreciation of their friendship and Nancy's shrewd advice convince him to make East Rodney his family's summer residence. As a sign of their renewed friendship, a dirt path forms between Nancy's farmhouse and Tom's estate.

Like the washed-out bridge in Harte's story, Carew's sprained ankle serves the purpose of bringing separated people into closer proximity so that readers can neither deny nor take for granted the distinctions between those people. Carew's immobility enables Tom to interact with the young people of East Rodney as a friend, not an upper-class outsider. Since there is no one to keep him company while hunting, Tom joins the local youth in activities unspoiled by mass culture like sailing, haycart parties, prayer-meetings, sewing societies, and most memorably, dancing in the schoolhouse hall and new barns. It is this change to Tom's ordinary routine that makes possible his friendship with Nancy. Jewett pushes this initial impetus into the background; Carew's ankle is discussed only in passing after we see Nancy and her uncle Ezra on their trip to Boston. Thus the story nearly buries the ankle incident which, if narrated in full, might prompt readerly sensations of disjunction and danger; like Harte in "Miggles," Jewett considers a narrative of traveler and male humiliation and chooses against it. This subtlety is typical of the story's pushing away of conventional heterosexual scripts. The travel delay and sporting injury were common devices in popular and 
high literary fiction of the 1880 s and 'gos for prodding active and speedy urban figures into the leisurely realm of courtship. Typically, the immobilized traveler was male and the nurturer was female; this fiction perpetuated the idea that women were nurses rather than travelers in search of adventure or rejuvenation themselves (Garvey 106-34). In contrast, Jewett's story avoids the scene of nurture and healing; we never see Nancy waiting on Carew at his bedside, serving Tom tea, or even gathering herbs. Readers are never encouraged to visualize Nancy in a service role.

Writing about these social types in this situation, Jewett could have written a typical summer boarder romance, in which a wealthy city boy attracts an innocent country girl only to betray her. Jewett avoids what was a conventional plot of nineteenth-century fiction. ${ }^{20}$ The story makes clear that Tom and Nancy fall a little bit in love when they first meet. Together Tom and Nancy are electric: Tom "scurrie[s]" down the steps of his club to meet her, and they tour the city on "the fleetest and lightest of feet," and "talked all the way" (313). Nancy wants to visit Boston so that she can let Tom know that Addie never cared for him, and while she is struggling to relay this information and its full import to Tom, Tom thinks of his East Rodney "boyish gallantries" (presumably with Nancy and Addie) "with a little uneasiness" (12). It is his feeling for Nancy that prevents Tom from revealing his near engagement to another girl. Yet they go their separate ways, remembering each other until Tom's later visit, when the affection is rekindled (or described as?) friendship. While Tom is married to a nameless, faceless urban wife and is spiritually unhappy, Nancy is not married and, perhaps as a result, is the center of a community that relies on her for teaching and the redrawing of school district lines. Thus the story suggests that the most permanent and satisfying of relationships is friendship, not marriage. To further diminish the importance of a "conjugal plot," Addie Porter's flitting with Tom and the other boys has no serious moral consequence for her or anyone else. Tom is uneasy when he remembers his "boyish gallantries," but he may read such socializing differently than a country girl would; in these years country youth socialized more comfortably with the other sex than did city youth of any class. ${ }^{20}$ As an adult, Addie forgets Tom's place in her trail of broken hearts, while Tom wistfully recalls his heady East Rodney flirtations. East Rodney women are eminently capable of handling city men; sex 
emerges from tourism, but sex is not exclusively an arena of conflict for New England girls. ${ }^{21}$

The story's style is designed around the potential for social/sexual disconnection. Marcia McClintock Folsom has shown how Jewett's The Country of the Pointed Firs has an "empathic style," in which the local Mrs. Todd and the narrator, a city boarder in Mrs. Todd's home, understand each other even before they speak. But Nancy and Tom often misunderstand each other, and the effect is dramatic irony, where the author and the readers know something that Nancy or Tom does not know. For Nancy, the trip to Boston is a wonderful experience that fulfills her dream of seeing first-rate dancing. For Tom, the visit is a delight, but a trial. He does not enjoy waking up early to meet Nancy on the morning after a Harvard assembly, and when Nancy asks him to take her to dancing, he dreams up an excuse instead of accompanying her to a lesson for children, the only dancing to be found so early in the day. Nancy is available in the evening, as a matter of fact, since her kind city cousins invite her to stay, but Tom feels the situation to be futile: he is "mindful of his own gay evening the night before, and of others to come, and the general impossibility of Nancy's finding the happiness she sought" (15). We have already seen that Tom deceives Nancy by not telling her about his engagement. Twenty years later, Tom walks into East Rodney expecting people to remember him and to care about the same things they did when they were young. But Addie does not remember him; the youth have new ways of entertaining themselves, and Nancy is happier than he. His misrecognition of East Rodney renders ironic his earlier thought about the impossibility of Nancy's happiness, or his imperious condescension earlier in the story- "Tom had an intimate knowledge, gained from several weeks' residence, with Nancy's whole world" (II). The latter clause, which initially appears to be written in the third-person omniscient, as if Jewett is stating an objective truth about Tom's ability to possess East Rodney, appears on a second read to be Tom's indirect discourse. As for Nancy, rather than chastising Tom for neglecting to write or never taking her to a real dancing class, she speaks only of fond memories. When he muses at Nancy's bedside that he is reconsidering the decision to sell his land, one wonders whether Nancy's behavior is intended to help him decide in the way that is best for her.

The narrative structure emphasizes economic subtext. The third sec- 
tion of the five part story, about Tom's return to East Rodney, is narrated from a third-person limited viewpoint. Tom and his male companion view the coast from an arriving steamer. They scrutinize the shore for its property value: "The two passengers were on the watch for landings and lookouts; in short, this lovely, lonely country was being frankly appraised at its probable value for lumbering or for building-lots and its relation to the real estate market" (22). Because of Nancy's shrewd optimism, she plays a key role in the economic subplot. When Tom meets her at her bedside she never encourages him to feel guilty for neglecting her; she even apologizes for not writing to him. Nancy's ability to teach Tom how to be happy again is what encourages him to change his plan to sell his East Rodney land. As Tom muses about the idea of building rather than selling, Nancy replies from an economic standpoint. She remarks that his living in East Rodney would raise the property value and therefore be a good investment for him and other land speculators. Indeed, Tom's decision to heed her advice leads to a small East Rodney boom: "It would be difficult to give any idea of the excitement and interest of East Rodney, or the fine effect and impulse to the local market" (39). In turn, Nancy receives a carrying chair, which expands her social life and mobility.

Jewett has been faulted for hiding the commercial nature of Maine country boarding by Elizabeth Ammons and Stephanie Foote. The famous friendship between the city narrator and Mrs. Todd of The Country of the Pointed Firs is, after all, a commercial one-the narrator is a paying guest in Mrs. Todd's home. The narrator is like Tom in that she is returning to a place she visited before in the hopes of recreating a wonderful experience. Elizabeth Ammons is right to point out that the repeated phrase "business" in descriptions of Mrs. Todd's home in the opening lines of The Country of the Pointed Firs ideologically masks New England's factories and bigger businesses. ${ }^{22}$ Such observations are important to keep in mind but misleadingly imply that boarding was not a business. It could be, however, a very big business: the boarding houses listed as private residences in railroad guides of the 1880 and gos sometimes accommodated up to ro to 20 people in as many as 13 guest rooms. ${ }^{23}$ By representing boarding, Jewett is representing New England business; in "The Life of Nancy," she begins to hint at the economic dimension of that business, more than she does in The Country of the Pointed Firs. 
In the story, Nancy does not play the typical role of a provincial who never travels, whose only knowledge and power are local. There is a parallel between bedridden Nancy and paralyzed Jim in Harte's story; an immobilized provincial is someone no traveling-reader wants to become. And as Sandra Zagarell has shown ("Troubling Regionalism"), Jewett portrays the passing on of the older values of a local gentry to a delegated readership of the "right sort" of urban elite. Just as Uncle Ezra knew Tom's grandfather, Nancy passes on her older values-respect for one's aunt, for instance-to Tom, the right sort of Boston businessman. Jewett does indeed use the sprained ankle to reveal the difference between the gracious, cosmopolitan Tom and the weak, arrogant Carew. Tom enjoys the local entertainment, because "he had known enough of the rest of the world to appreciate the little community of fishermenfarmers" ( 1 I-I2), while Carew turns into "but a complaining captive with a sprained ankle" (12). But such statements about Tom's knowledge need to be read alongside evidence of Nancy's knowledge. ${ }^{24}$ And Nancy does not just teach Tom, she travels herself.

The story opens with a section about Nancy's visit to Boston, which is explained as an incidental and natural extension of a farmer's circuit between home and market. She accompanies her uncle Ezra, who lives in the hills just outside Boston, in his regular delivery of peaches from his farm. At first the danger of the unfamiliar city streets is raised, but somewhat like in Harte's story, these initial misgivings are overcome: the gruff Ezra forbids a trip to the theater but relents when he recognizes that a Maine girl is used to walking the four-and-a-half-mile distance between the depot and his home. ${ }^{25}$ While Ezra goes about his business, Nancy becomes a tourist, and Tom her native guide. Together Tom and Nancy tour Faneuil Hall, Charlestown, and other sights that "thrill" her "patriotic heart" (13). Although Nancy can no longer tour Boston when she grows old, her joy in society and movement continues to lend her life meaning; when moralists chide her for thinking about dancing on her deathbed, she cites David dancing before the Lord. Thus the story portrays travel as ubiquitous and reciprocal-farmers tour Boston, and college students tour Maine.

Folsom remarks that Jewett's empathic style "allows full expression to what is, but implies stasis." For this reason, it "tends away from action, change, and the future" (89). But "The Life of Nancy" is all about the changing relationship between East Rodney and Boston. The story is 
remarkable in the degree to which it does not preserve East Rodney as it was in the early days of Nancy and Tom's friendship. Hence it should add to critics' understanding of the variation within Jewett's corpus. The story is not focused on the urban elite and their ethically correct or incorrect attitudes toward country people, it is focused on the colliding of country and city. Some critics have praised Jewett's reading of New England's historical change because she builds scenes of understanding and non-invasive intimacy between essentially unlike people. In the process, these critics have over-emphasized the degree to which Jewett's unlikely friendships focus on dominant-subordinate relations between an educated, mobile narrator and marginal, regional characters. ${ }^{26} \mathrm{By}$ praising Jewett's "ethical" relation to her characters, they construct Jewett's characters into subordinate people, but in this story, Nancy is not portrayed as subordinate. Like Jewett herself, Nancy is a regional person with biographical and spiritual affiliation both inside and outside of high culture circles.

\section{$\approx \approx$}

Louis Renza, Richard Brodhead, and Elizabeth Ammons fault Jewett for hiding the presence of tourism and industry in her depiction of place, but such a claim cannot be made about the writing by Harte and Jewett discussed here. ${ }^{27}$ Neither is this writing reducible to what Amy Kaplan provocatively calls "literary tourism" ("Nation" 252) because there are differences as well as similarities between this writing and the consolidation of national power. Harte and Jewett write about a practice of human relations between travelers and locals that characterized their places and was in danger of passing away. During Harte's final years in California, more people were visiting the West as prospective residents, investors, health seekers, or tourists, and the most powerful of these newcomers influenced the way strangers greeted each other on the road or the way that residents made a living. Harte's sketches suggest that there are local stories that this modern traveler will not see unless nature or faulty technology, which is always a natural force interfering with human plans, obliges them to look more carefully. In "Miggles," Harte's in-between status and the contemporaneity of stagecoach travel-a staple of tourist routes in California into the I880sare relatively hidden. But the story forces travelers into sociability with other people's realities. It corrects traveler fantasies just as would a good 
tourist guide. Jewett's story takes slow, personable travel into her present day. The story suggests that economically sophisticated tourist development may not prevent locals and travelers from having to understand each other. If travelers come back twenty years later, the locals may have changed and they may have become interested in shaping economic development. Like Harte's story, the story figures unequal social relations in its portrayal of bodies; travelers' sore limbs are contrasted to more severe medical problems among the local residents.

Both stories celebrate values known then and now as feminine, but in a wry rather than conventional way. The feminine is removed from its customary role of redemption. The stories focus on the work and self-compromise of women and others who are assigned the tasks of making meals, shelter, or sociability. Harte's story reminds readers that the people who make travel comfortable and possible are in danger of being considered "loose," while Jewett removes the characters Nancy and Addie from what might be construed as demeaning service roles. Most disappointing to those travelers who expect sex as well as comfort, the women's romantic desire for someone other than the travelers, and the women's ability to negotiate that relationship successfully, is made clear. Both stories vacillate between a danger and seduction script and a script more empowering for the female characters.

Harte and Jewett portrayed an activity of unplanned intimacies between strangers that they perceived to be nearly extinct, and therefore twenty-first-century readers might think emergency hospitality can be written off as yet another nineteenth-century activity that shifted from an activity of necessity to recreation during these years. The experience of emergency hospitality became commodified in their lifetimes, and they contributed to its commodification. Yet commodification and economic development more generally are not monolithic. Hospitality was commercial as well as sociable even in the nineteenth century, as documented by Paton Yoder's study of absentee tavern landlords and Dona Brown's study of rural men and women working to attract city boarders. The present-day bed and breakfast, clear ancestor of the boarding house, has commodified the experience of intimacy between traveler and host less ambiguously than Harte's and Jewett's writing did. British Airways advertisements in The New Yorker in the r99os tried to convince passengers that flying in the company's business class felt like a return to the mother-a classic mother from the era of their youth-a 
message that elides both flight crews and travelers' real mothers. ${ }^{30}$ In comparison to British Airways, Harte and Jewett are creative and slightly subversive in their attempts to write a version of history in which nature and other people's bodies impinge on travelers into the present day. In Harte's and Jewett's lifetimes, unplanned intimacies during travel never became wholly a thing of the past; Harte slept in a hayloft in a hamlet near the Wallenstadt Lake in Switzerland long after any "frontier" had closed there, and he complained about it bitterly (Nissen $\mathrm{I}_{7} 6$ ). In the twenty-first century, unscripted and uncommodified human interactions continue to coexist with commercial interactions, in all countries, and it does not take a great deal of travel experience to know that such interactions rarely have the solitary effect of shoring up a cosmopolitan sense of one's own superiority. In this regard like the environmentalists of today, who are calling for sustainable development rather than conservation alone (Short, Cohn-Bendit), Harte and Jewett were trying to shape history not flee it.

University of Leicester

\section{NOTES}

For their help I wish to thank June Howard, Sara Eddy, Janice Koistinen-Harris, Licia Calloway, Ralph Coury, Kelly Thomas, and Ian Leong.

I. I write both travelers and tourists because no firm line can be drawn between the former (business travelers or economic migrants) and the latter (pleasure or health seekers). Fifer's book on the West illustrates the fluidity of travel motives: "whether traveling for pleasure, health, education, or part-business purposes, they [travelers] were often also potential settlers or investors in the West" (5). As for the moral distinction, first proposed by Fussell, between travelers who are independent of commercialism and tourists who are mired within in it, I argue, after Buzard, that the distinction is a class one. It emerged from the elite's reaction against the increasingly lower-class tourists who began to predominate in Europe and North America after the American Civil War. Jewett and Harte are reacting against lower-class tourists, but, as I will argue, not only from the position of a cultural elite. On the continuing popularity of Fussell's distinction outside of academia, see Espey.

2. See Pattee; Brooks; Austin; Ziff 73-92, and less directly, Spiller et al. 843-6r.

3. One recent useful exception is Floyd.

4. Renza 56; Ammons; Brodhead.

5. Fifer's history of the tourism, information, and transport industries in the West, and Dona Brown's history of the construction of New England demonstrate that tourism cannot be studied separately from economic development. 
6. See Fifer on the West; Dona Brown on New England and the Northeast; Dunlop on the Midwest broadly defined, and Sears on the Northeast. Literary scholars will recognize that these changes in eating, sleeping, and travel arrangements are also amply documented and commented upon by Nathaniel Hawthorne, Margaret Fuller, Bayard Taylor, Hartiet Martineau, Maria Cummins, William Dean Howells, Henry James, Isabella Bird, and Theodore Dreiser, but recent historical accounts are more systematic than the writers in their discussions of finances and class segregation, and hence I cite them instead.

7. Demars and Nash document similar battles between various social groups in determining how Yosemite National Park would be run.

8. One telling exception is women homemakers, who take these opportunities to learn about other people's domestic practices and sometimes to draw conclusions about their level of civilization. Kirkland feels guilty when Pottawattamie Indians show her gentle courtesy "though it was obvious that the visit, which inconvienced them, could only have been caused by the most impertinent curiosity" (I4I). Eliza Farnham admits to longing for rainstorms so that she can satisfy her curiosity about how her less refined neighbors manage their households.

9. See Buzard 58 on cultured travelers' quest for the special, original experience not found in guidebooks.

Io. I say story and not motif to emphasize the aftermath, the way emergency hospitality generates social narrative.

I I. I say first published because Charles Johannigsmeier's work on newspaper syndication of local color writing suggests that the audience of such stories was much wider than scholars have typically accounted for. The stories were reprinted in cheap newspapers across the country and abroad. See also Nissen 20I-4, Glazener 206-30. Harte's friend created the Overland Monthly to rival the Atlantic Monthly and other Eastern magazines as a national vehicle of arts and letters; the magazine's layout and contents (politics, anthropology, travel, fiction, and poetry) were nearly identical to those of the Atlantic.

12. The narrator is female, but searches in Poole's Index to Periodical Literature, the National Union Catalog of Manuscript Collections, and nineteenth-century editions of Who's Who in America yielded no information about the author, who may be male or female.

13. Although Hoberman does not discuss de-centered theories of history, his rereading of Welty's emergency hospitality story helped me think through this point. On "competing reality" as a motif of realism, see Kaplan, The Social Construction of American Realism.

14. One of the changes of the Gilded Age was that urban people ceased to rely on neighborhood networks to build houses, deal with garbage, and provide public safety (Wiebe 14 ). Frontier hospitality is fondly remembered because it differed from the increasingly bureaucratic urban public services.

15. While investors came from many cities and countries, Fifer documents that Bostonians and New Englanders (rather than New Yorkers or Chicagoans or Philadelphians) were the most prominent as consumers, investors, entrepreneurs, tour organizers, promoters, writers, and publicists (Io). 
I6. See Letter 33; "On an Extinct Public Institution"; "Notes by Flood and Field"; "Stage-Coach Conversations"; "A Lonely Ride."

I7. Buzard coins and conceptualizes the term "token of acculturation" (157, 59) to denote experiences and objects valued by travelers as signs of their increasing cultural prestige, one of which was an evening spent in a peasant's cabin. Although Buzard focuses on British and American travel in Europe, this aspect of his analysis applies.

I8. With its group of disparate people who are brought closer together in the face of a challenging environment, it resembles the film Stagecoach (1939). Harte's story differs from the film in that its characters feel the lack of sympathy in their group and temporarily regain it without the threat of marauding Indians. Following Beebee's theory of generic instability, in which a text's ideology is most visible in its vacillations between specific genres, then, one can say that Harte's story vacillates ideologically between Westerns and local color fiction.

I9. See for example Howells and Taylor.

20. She sent the first draft to Horace Scudder in November 1894 , Letter to Horace Scudder.

21. Elizabeth Stuart Phelps' The Gates Ajar (I868) alludes to a young woman hurt by a summer boarder's casual flirtation as a story so familiar that it need not be elucidated; Jewett's novel A Marsh Island (1885) features a young man who nearly proposes to the daughter of a farming family; and William Dean Howells' The Landlord at Lion's Head (r897) features the son of a country inn owner who fell in love with a guest but only managed to marry her after her disastrous first marriage to a dishonest Italian. The thwarted romance between Alma Leighton and Angus Beaton in Howells' The Hazard of New Fortunes ( 1890 ) also counters convention. They meet in St. Barnaby's, New Hampshire, where Beaton boards in Alma's home. Although it is Beaton (callow urban aesthete) who spurns Alma (aspiring provincial artist) when she arrives in New York City, it is Alma who finally rejects Beaton.

22. On the differences between country and city courtship and other socializing among youth, see Freedman and D'Emilio 74-77. William Dean Howells fondly writes in The Landlord at Lion's Head, that kissing and holding hands were more acceptable in the country than they were in the city.

23. This marginalization of the threat of seduction and self-abandonment makes the story very different from the contemporaneous urban-rural romance text of The Virginian (1902). Like Willa Cather in My Ántonia, Jewett centers attention on a regional figure but avoids a romantic connection between the urbanized narrator and Ántonia. For this reading of Cather and Wister, see John Murphy.

24. Writes Ammons, "These absences imply that in Dunnet there is no division between home life and work life because there is no developed capitalist-based class system with managers (the rich) and workers (the poor) - both of which by the time Jewett wrote The Country of the Pointed Firs were standard features not only of city life but also of small-town life" (84). On the consumerist perspective of the metropolitan narrator of Country, see also Foote, who reads the narrator as a consumer of Dunnet Landing who engages in acts (like looking through a window) 
associated with urban realism and the city as the preeminent space of commodity display. While perceptive, this argument equates consumerism with exploitation, an equation "The Life of Nancy" seeks to mitigate.

25. New York Central and Hudson River Railroad Co. r34; Green Mountain Railroad; Maine Central Railroad Company.

26. For example, she teaches all the academic subjects except Greek to a local boy who attends Bowdoin College, the same college the New England writer Nathaniel Hawthorne attended.

27. Just as the sprained ankle helped Tom socialize with country youth on their terms, a traffic jam stops the wagon long enough for Nancy and Tom to obtain Uncle Ezra's permission.

28. For example, the entry on Jewett in Fetterley and Pryse's anthology of women regionalists characterizes Jewett's relation to her characters as an ethical dilemma: "how can she [Jewett] portray the lives of regional people without betraying them? How can she create the conditions necessary for silent persons to speak their secrets without writing fiction that will 'stuff' her characters and put them in a sideshow for gawkers to mock?" (186). Dona Brown's analysis of poor New England women's role in promoting tourism indicates that New England women were not entirely silent.

29. Nor in other stories by Jewett, including "A Late Supper" and "An Everyday Girl."

30. The first ad, "The new Club World cradle seat. Lullaby not included" ( 5 Feb. $1996: 3$ ), features a black and white photograph of a young white woman holding a baby in her arms. Her hair is in a modest 1950 os wave, and she is wearing a simple sweater and a single strand of pearls. The baby's head is replaced by a color shot of the head of a portly fifty-something white business man leaning against the blue airline seat. A few months later, a similar ad designed around a black business man and his own classic childhood appeared ("The new Club World seat. A huge improvement" [I I March I996:8]). Both ads seek to reinforce the symbolic maleness of all travelers from the nineteenth century to the present and the symbolic femaleness of the people in the hospitality industry.

\section{WORKS CITED}

Ammons, Elizabeth. "Material Culture, Empire, and Jewett's Country of the Pointed Firs." New Essays on The Country of the Pointed Firs. Ed. June Howard. New York: Cambridge University Press, 1994. 81-100.

Austin, Mary. "Regionalism in American Fiction." English Journal 21 (1932): 97-107.

Bederman, Gail. Manliness $\mathcal{F}^{2}$ Civilization. Chicago: University of Chicago Press, I995.

Beebee, Thomas O. The Ideology of Genre: A Comparative Study of Generic Instability. University Park: Pennsylvania State University Press, 1994. 
Blanchard, Paula. Sarah Ome Jewett: Her World and Her Work. Reading, MA: Addison-Wesley, 1994 .

Bourdieu, Pierre. The Field of Cultural Production: Essays on Art and Literature. New York: Columbia University Press, 1993.

British Airways. "The New Club World Cradle Seat." New Yorker. 1996.

Brodhead, Richard. Cultures of Letters: Scenes of Reading and Writing in NineteenthCentury America. Chicago: University of Chicago Press, 1993.

Brooks, Van Wyck. New England Indian Summer I865-1915. New York: Dutton, 1940. Brown, Dona. Inventing New England: Regional Tourism in the Nineteenth Century. Washington, DC: Smithsonian, I995.

Brown, Elsa Barkley. "What Has Happened Here? The Politics of Difference in Women's History and Feminist Politics." 1995. Second Wave Reader: A Reader in Feminist Theory. Ed. Linda Nicholson. New York: Routledge, 1997. 272-87.

Brown, M. Edward. "A Winter Adventure on the Prairie." Atlantic Monthly I870: $501-9$.

Buzard, James. The Beaten Track: European Tourism, Literature, and the Ways to Culture, 1800-1918. New York: Oxford University Press, 1993.

Cohn-Bendit, Daniel. "Street Cred." [London] Guardian. 2 I August 2002: 7.

Demars, Stanford. The Tourist in Yosemite, $1855-1985$. Salt Lake City: University of Utah Press, I99ז.

Dunlop, M. H. Sixty Miles From Contentment. New York: Basic Books, I 995.

Espey, Paul. "Remarks." Writing the Journey Conference. University of Pennsylvania. June 1999. http://www.english.upenn.edu/Conferences/Travelg9/sess.html

Farnham, Eliza. Life in Prairie Land. Urbana and Chicago: University of Illinois Press, 1988.

Fetterley, Judith, and Marjorie Pryse, eds. American Women Regionalists, I850I9IO. New York: Norton, I992.

Fifer, J. Valerie. American Progress: The Growth of the Transport, Tourist, and Information Industries in the Nineteenth-Century West. Boston: Globe Pequot Press, I988.

Floyd, Janet. "Mining the West: Bret Harte and Mary Hallock Foote." Soft Canons: American Women Writers and Masculine Tradition. Iowa City: University of Iowa Press, 1999. 202-18.

Folsom, Marcia McClintock. "'Tact is a Kind of Mind-reading': Empathic Style in Sarah Orne Jewett's The Country of the Pointed Firs." Critical Essays on Sarah Ome Jewett. Ed. Gwen L. Nagel. Boston: G.K. Hall, 1984. 76-88.

Foote, Stephanie. "'I Feared to Find Myself a Foreigner': Revisiting Regionalism in Sarah Orne Jewett's The Country of the Pointed Firs." Arizona Quarterly 52:2 ( $x 996): 37-6 x$.

Freedman, Estelle B. and John D'Emilio. Intimate Matters: A History of Sexuality in America. New York: Harper and Row, 1988.

Fuller, Margaret. Summer on the Lakes. I843. The Essential Margaret Fuller. Ed. Jeffrey Steele. New Brunswick: Rutgers University Press, 1992. 69-225.

Fussell, Paul. Abroad: British Literary Traveling Between the Wars. Oxford and New York: Oxford University Press, I980. 
Garvey, Ellen Gruber. The Adman in the Parlor: Magazines and the Gendering of Consumer Culture, 1880 s to I 9 Ios. New York: Oxford University Press, 1996.

Glazener, Nancy. Reading for Realism: The History of a U.S. Literary Institution, 1850-1910. Durham and London: Duke University Press, 1997.

Green Mountain Railroad. Green Mountain Byways. New York: Press of American Bank Note Co., i 888.

Harte, Bret. "In the Country." Rpt. Sketches of the Sixties. By Harte and Mark Twain. San Francisco: John Howell, 1926. I5-18.

- Letter 33. Springfield Republican i i Sept. I867. Rpt. Bret Harte's Califomia. Ed. Gary Scharnhorst. Albuquerque: University of New Mexico Press, 1990. I30-35.

—_. "On an Extinct Public Institution." Californian. Rpt. Sketches of the Sixties. By Harte and Mark Twain. San Francisco: John Howell, 1926. 19-24. . "Miggles." 1869. The Luck of Roaring Camp, Suzy: A Story of the Plains. Argonaut Edition. New York: P.F. Collier \& Son, I899. 37-55.

- "Notes by Flood and Field." 1870. The Works of Bret Harte. Vol. 2. Boston: Houghton Mifflin, $1883,60-86$.

- "Stage-Coach Conversations." Califomian, 1866. Stories and Poems and Other Uncollected Writings. Boston: Houghton, Mifflin, I914. 155-57.

. "A Lonely Ride." I870. The Works of Bret Harte. Boston: Houghton Mifflin, $1883.46-53$.

Hoberman, Michael. "Demythologizing Myth Criticism: Folklore and Modernity in Eudora Welty's 'Death of a Traveling Salesman.'" The Southern Quarterly 30 (1990): 24-34.

Holder, J. B. "Along the Florida Reef." Harper's Monthly 42 (I $87 \mathrm{I}): 355^{-63}, 515-$ $26,706-18,820-30$.

Howard, June. "Unraveling Regions, Unsettling Periods: Sarah Orne Jewett and American Literary History." American Literature 68 (I996): 365-84.

Howells, William D. "By Horse-Car to Boston." 1870. Suburban Sketches. Boston: Houghton, I898. 9I-I I5.

Jewett, Sarah Orne. Letter to F. M. Hopkins. 22 May I893. Sarah Ome Jewett Letters. Ed. Richard Cary. Waterville, ME: Colby College Press, I967. 64-65.

- Letter to Horace E. Scudder. 22 November, 1894 . Sarah Orne Jewett Letters. Ed. Richard Cary. Waterville, ME: Colby College Press, r967. 71. - "The Life of Nancy." The Life of Nancy. Boston: Houghton Mifflin, 1895. $\mathrm{I}-42$.

Johanningsmeier, Charles. Fiction and the American Literary Marketplace, I860r900. Cambridge: Cambridge University Press, 1996.

Johnson, Susan Lee. "'Domestic' Life in the Diggings: The Southern Mines in the California Gold Rush." Over the Edge: Remapping the American West. Ed. Valerie J. Matsumoto and Blake Allmendinger. Berkeley: University of California Press, I999. 107-32.

- "Sharing Bed and Board: Cohabitation and Cultural Difference in Central Arizona Mining Towns, 1863-73." The Woman's West. Ed. Susan Armitage and Elizabeth Jameson. Norman: University of Oklahoma Press, I987. 77-92. 
Kaplan, Amy. "Nation, Region, and Empire." The Columbia History of the American Novel. Ed. Emory Elliott. New York: Columbia University Press, I99I. 24066.

- The Social Construction of American Realism. Chicago: University of Chicago Press, 1988.

Kingston, Maxine Hong. Tripmaster Monkey. New York: Knopf, 1989.

Kipling, Rudyard. American Notes. 1891. Ed. Arrel Morgan Gibson. Norman: University of Oklahoma Press, I98I.

Kirkland, Caroline M. A New Home, Who'll Follow? I839. Ed. Sandra Zagarell. New Brunswick: Rutgers University Press, I990.

Limerick, Patricia Nelson. Legacy of Conquest: The Unbroken Past of the American West. New York: Norton, 1987 .

Maine Central Railroad Company. The Front Door-Yard of the Country, and What it Contains. Boston: Passenger Dept., Maine Central Railroad, 1888.

Marshall, W. G. Through America: or, Nine Months in the United States. London: Sampson Low, Marston, Searle, and Rivington, r88r.

Murphy, Jacqueline Shea. "Replacing Regionalism: Abenaki Tales and 'Jewett's' Coastal Maine." American Literary History 1o (1998): 664-9o.

Murphy, John J. "The Virginian and Ántonia Shimerda: Different Sides of the Western Coin." Women and Western American Literature. Ed. Helen Winter Stauffer and Susan J. Rosowski. Troy, NY: The Whitston Publishing Co, I982. I62-78.

Nash, Roderick. Wilderness and the American Mind. 1967. New Haven: Yale University Press, I982.

New York Central and Hudson River Railroad Co. Summer Homes and Excursions Embracing Lake, River, Mountain and Seaside Resorts. Albany: Mrs. S. S. Colt, I87I.

Nissen, Axel. Bret Harte Prince and Pauper. Jackson: University of Mississippi Press, 2000.

Pattee, Fred Lewis. A History of American Literature, With a View to the Fundamental Principles Underlying Its Development. Boston: Silver, Burdett and Co., I897.

Renza, Louis A. "A White Heron" and the Question of Minor Literature. Madison: University of Wisconsin Press, 1984.

Richardson, Albert. Beyond the Mississippi. Hartford, CT: American Publishing Co., I867.

Sears, John. Sacred Places: American Tourist Attractions in the Nineteenth Century. 1989. Amherst: University of Massachusetts Press, 1998.

Short, Clare. "Prize Fight." [London] Guardian. 2 I August 2002: 6.

Spiller, Robert E., Willard Thorp, Thomas H. Johnson, Henry Seidel Canby, and Richard M. Ludwig, eds. Literary History of the United States. Third ed., rev. New York: MacMillan, 1963.

Stegner, Wallace. Introduction. The Outcasts of Poker Flat and Other Tales. By Bret Harte. New York: Signet, 196r. vii-xvi.

Stewart, George R., Jr. Bret Harte: Argonaut and Exile. 1935. Port Washington, NY: Kennikat Press, I959. 
Taylor, Bayard. "Travel in the United States." Atlantic Monthly i9 (April r867): $477-83$.

Unruh, John D., Jr. The Plains Across: the Overland Emigrants and the Trans-Mississippi West, I 840-60. Urbana: University of Illinois Press, I979.

Ward, Julius. "Moosehead Lake." Harper's Monthly 5I (I 875): 350-65.

Weber, Clara, and Carl J. Weber. A Bibliography of the Published Writings of Sarah Ome Jewett. Waterville, ME: Colby College Press, I949.

Wiebe, Robert. The Search for Order: $1877-1920$. New York: Hill and Wang, I967. Yoder, Paton. Taverns and Travelers: Inns of the Early Midwest. Bloomington: Indiana University Press, r969.

Zagarell, Sandra A. "Response to Jacqueline Shea Murphy's 'Replacing Regionalism." American Literary History 10.4 (1998): 69I-97.

. "Troubling Regionalism: Rural Life and the Cosmopolitan Eye in Jewett's Deephaven." American Literary History I0.4 (Winter 1998): 638-63."

Ziff, Larzer. The American 189os. New York: Viking, 1966.

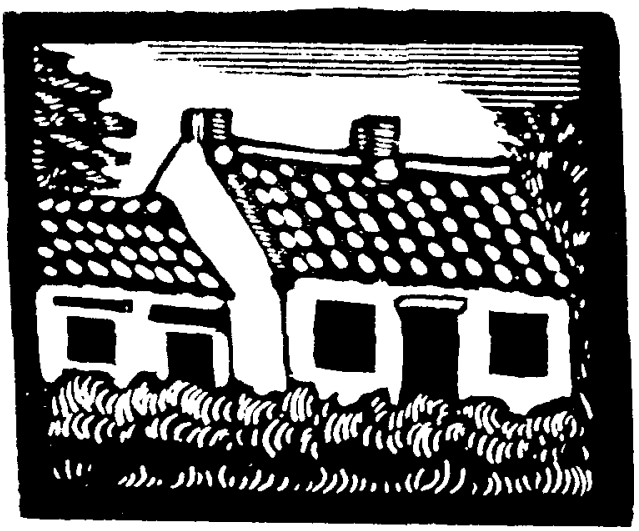

